Journal of Finance and Banking Review

Journal homepage: www.gatrenterprise.com/GATRJournals/index.html

J. Fin. Bank. Review 2 (1) 1 - 8 (2017)

\title{
Determinant of Debt Policy: Empirical Evidence from Indonesia
}

\author{
Hansen Viriya ${ }^{1}$ and Rosita Suryaningsih ${ }^{2 *}$ \\ ${ }^{1,2}$ Universitas Multimedia Nusantara, Scientia Garden, J1 Boulevard Gading Serpong, 15811, Tangerang, Indonesia
}

\begin{abstract}
Objective - The objective of this study is to observe the effects of managerial ownership, institutional ownership, dividend policy, firm growth, business risk, liquidity, and profitability on debt policy.

Methodology/Technique - Using the purposive sampling method, secondary data were retrieved from 16 firms that fulfil the criteria of this study. Analysis was made through the multiple regression method.

Findings - The results of this research indicate that: (1) managerial ownership has a significantly negative effect on debt policy, (2) institutional ownership has no positive effect on debt policy, (3) dividend policy has no negative effect on debt policy, (4) firm growth has no positive effect on debt policy, (5) business risk has a significantly positive effect on debt policy, (6) liquidity policy has a significantly negative effect on debt policy, (7) profitability has no negative effect on debt policy, (8) managerial ownership, institutional ownership, dividend policy, firm growth, business risk, liquidity, and profitability, simultaneously, have a significant effect on debt policy.

Novelty - This study implies that all the independent variables are related to debt policy, simultaneously. This shows that the regression model has an appropriate fit in estimating the accrual value of the model.
\end{abstract}

Type of Paper: Empirical

Keywords: Business Risk, Debt Policy, Dividend Policy, Liquidity and Profitability, Managerial and Institutional Ownership.

JEL Classification: G32, G35.

\section{Introduction}

In the year 2015, the world's economy, especially in Asia, began to weaken as a result of the increasing rate of the USD. This happened because the United States was regaining its economic crisis that had occurred earlier and was now pulling back the funds given to several Asian countries. The fund withdrawal made an impact on many Asian countries including Indonesia. From the beginning of 2014 until the end of August 2015, the exchange rate of the Rupiah against the USD has fallen drastically, which is from 12,000 Rupiah going through 14,500 Rupiah (www.bi.go.id).

The increasing rate of the USD had also impacted share trading in Indonesia. This could be seen from the drop of the IHSG (JCI). In the first quarter of 2015, the value topped at 5,500 but in the second quarter, the

\footnotetext{
* Paper Info: Received: February 4, 2017

Accepted: March 25, 2017

* Corresponding author:

E-mail: rosita@umn.ac.id

Affiliation: Universitas Multimedia Nusantara, Indonesia
} 
value dropped to 4,900 and it decreased further in September 2015 (www.idx.co.id). Therefore, obtaining funding through the shares was not a wise decision.

The impact of the USD was also felt by various other sectors, particularly, entrepreneurs and industries that were using imported sources. They feared that they were unable to cover the production costs and the weight of the debt in the form of the USD. However, the Central Bureau of Statistics stated that the production growth of manufacturers in Indonesia was increasing. This means that even though the country was facing the impact of the USD, manufacturing production was positively growing.

Aside from that, the Bank of Indonesia (Central Bank) further indicated that the amount of credit given to UMKM (Small and medium enterprises), Non-UMKM, and Banking of the various sectors of the industries had increased while Non-Performing Loan (NPL) was said to be undergoing the same condition. These issues could make creditors like the banks to be more careful and to take precautions when giving out loans especially to these firms. Because of that, banks made some stipulations which states that firms thinking of taking bank loans need to have appropriate debt policies that can fit into the bank's criteria so as to enable the firms to obtain the loans for their firms' operation.

Debt policy is a policy that aims to determine the amount of debt a firm has so that it remains stable. The consequence of using debt is none other than as an obligation to pay interest. Debt policy considers what percentage of interest is to be paid and the time period that is decided within an agreement. In this regard, the debt policy of a firm is a necessity for the firm to manage well for this debt could be highly utilized. This study will observe the effect of ownership structure that is divided into managerial ownership and institutional ownership, dividend policy, firm's growth, business risk, liquidity, and profitability towards on debt policy.

\section{Literature Review}

\subsection{Agency Theory}

The agency theory assumes that every individual's action is based on its respective interests. In banking, the principals want a return as high as possible for their investments in the firm and this is reflected by the increase of dividends per share. On the other hand, the agents would also wish to gain accommodation such as incentives for their achievement in work. Thus, when there is no suffice supervision, then the agents could manipulate some data in order to show that the firm's target has been reached (Wahyudiharto, 2009) cited in Susanto (2011).

\subsection{Pecking Order Theory}

Myers and Majluf (1984), cited in Hardiningsih and Oktaviani (2012) mentioned the Pecking Order Theory which explains that a firm has a hierarchy of funding sources. The assumption of the pecking order theory, proposed that firms prefer to obtain internal fundings more than external fundings ( see Brealy \& Myers, 1996) cited in Hardiningsih and Oktaviani (2012). At the time when the external funding is needed, the firm will choose to issue the safest security, starting from bonds, convertible bonds and eventually stocks.

\subsection{Debt Policy}

Dharmastuti et al. (2003) cited in Nuraina (2012) states that debt is one of the external funding used by a firm to replenish its needs. Modigliani and Miller (1999), cited in Nuraina (2012), said that if the firm's debt is too high, it will bring a risk of bankruptcy and so increases agency cost. Based on this, it can be deduced that the increase of debt will make the firm's value go up. However, at some point, the use of debts could cause the firm's value to fall.

\subsection{Managerial Ownership}


Managerial ownership refers to the shares owned by individuals who hold the position of director or commissioner in the company (Susanto, 2011). Masdupi (2005) cited in Susanto (2011) explains that the action of giving a part of the shares to managers carries some purpose which include: (1) to attract and preserve the potential managers and (2) to direct the managers' actions closer to shareholders' interest, especially to maximize the shares price. Kohardinata and Herdinata (2013) mentioned that in firms where the majority of the shares are owned by managers, it is the managers who will choose to facilitate the firm's investment by using the firm's own capital. This is because the financial risks would be lower than using debts. The hypothesis formulated thus reads as:

$\mathrm{Ha}_{1}$ : The managerial ownership has negative effects towards debt policy.

\subsection{Institutional Ownership}

Institutional ownership refers to the proportion of shares owned by the institution at the end of the year. This is measured by percentage (Nabela, 2012). From a study conducted, Wahidahwati (2002), cited in Yenatie and Destriana (2010), explains that the stockholders are more concerned about the increase in share prices and obtaining profits from the distributed dividend. Moreover, when the funding is conducted through issuing new shares, then the percentage of ownership as owned by the previous shareholder will be lower. This is followed by a lower dividend. The hypothesis formulated thus reads as:

$\mathrm{Ha}_{2}$ : The institutional ownership has positive effects towards debt policy.

\subsection{Dividend Policy}

The dividend policy is applied to control the board's decision on how much earnings would be distributed to stockholders and how much earnings would be reinvested or retained in earnings (Nabela, 2012). In the study conducted by Paramu (2006), cited in Farida, Prasetyo, and Herwiyanti (2010), it was noted that the distribution of dividends by a firm would increase the prosperity of the firm's stockholders, thereby producing a positive expectation. This will make a firm easier to obtain fundings through stocks, with the result that it potentially makes the debt portion lower. Yenatie and Destriana (2010) observed that firms which hold a high dividend payout ratio (DPR) prefer to use its capital for funding as the payment for dividend. This will commit the firm into increasing the payment of dividends. Usually, the payment of dividend is only executed after the debt interests and installments have been executed. Therefore, the managers will be more careful and debts will be used more efficiently. The hypothesis formulated for this reads as:

$\mathrm{Ha}_{3}$ : The dividend policy proxied by dividend payout ratio (DPR) has negative effects towards debt policy.

\subsection{Firm's Growth}

According to Hardiningsih and Oktaviani (2012), a firm's growth is a representation of the business development which had occurred in the current period as compared to previous years. A major increase in asset growth gives creditors confidence in offering a loan to the firm. This is so because when a firm is unable to meet its obligations, there is a warranty of assets that could be used as repayment. Ang (1997), cited in Widjaja (2014), states that an increase in the amount of assets, followed by an increase in operating income will enhance the confidence of external creditors towards a firm. This is based on the creditors' trust for the invested funds that were guaranteed by the firm's assets. The hypothesis formulated for this reads as:

$\mathrm{Ha}_{4}$ : The firm's growth has positive effects towards debt policy.

\subsection{Business Risks}

According to Farida et al., (2010), a firm is said to be facing a business risk when it generates a fluctuating income from term to term. The higher business risk faced by the firm will make it more cautious in conducting funding from debts. According to Harjanti and Tandelilin (2007), a firm having a large amount of debt will 
experience an increase in bankruptcy risk. Because of that, the firm will try its best to maintain its debt portion so as to avoid endangerment of debt. The hypothesis formulated for this thus reads as:

Has: The business risks have negative effects towards debt policy.

\subsection{Liquidity}

Liquidity is an aspect showing the firm's ability in fulfilling its obligation that needs to be paid soon (Narita, 2012). The higher the current ratio of a firm is, the more confident creditors are, thus the easier it is for the firm to acquire funding from external parties. According to Narita (2012), a firm with high liquidity gives creditors the confidence that loans will be repaid since a firm with higher liquidity will encourage it to use a higher amount of debt. The hypothesis formulated thus reads as:

Ha6: The liquidity proxied by current ratio (CR) has positive effects towards debt policy.

\subsection{Profitability}

Profitability is the firm's capability in generating income at a specific period. High return on firm assets indicates that its earning rate is also the same. Thus when the firm needs funding, it will make use of its retained earnings first. A firm with a high return rate tends to use debt at a relatively low amount. This happens because with a high return rate, the fund needed for business growth or investments would be sufficient, just by using retained earnings (Susanto, 2011). The hypothesis formulated thus reads as:

$\mathrm{Ha}_{7}$ : The profitability proxied by return on assets (ROA) has negative effects towards debt policy.

\section{Methodology}

\subsection{Overview of Research's Object}

The sample for this study was selected by using purposive sampling method and it totaled up to 16 firms which were simultaneously registered in the manufacturing sector in the Indonesia Stock Exchange for the year 2010-2013. This information was extracted from their respective financial reports and their currency exchange was in the form of the Rupiah currency. The firms executed their distribution of cash dividends, and each had a positive assets growth with institutional ownership structure of above 5\%, and a managerial ownership structure.

\subsection{Research's Variable}

The method used in this research is based on causal study which relies on variables.

Dependent Variables

The dependent variable in this research is Debt Policy proxied by Debt to Total Asset Ratio is calculated according to Weygandt, Kimmel, and Kieso (2013) as:

$$
\text { DTA }=\frac{\text { Total Debts }}{\text { Total Assets }}
$$

Independent Variables

1. Managerial Ownership

Managerial ownership calculation is calculated according to Kohardinata and Herdinata (2013) as:

$$
\mathrm{KM}=\frac{\text { Total Management's Shares }}{\text { Outstanding Shares }}
$$


2. Institutional Ownership

Institutional ownership is calculated according to Kohardinata and Herdinata (2013) as:

$$
\mathrm{KI}=\frac{\text { Total Institutional's Shares }}{\text { Outstanding Shares }}
$$

3. Dividend Policy

Dividend Policy proxied by Dividend Payout Ratio is calculated according to Murtiningtyas (2012) as:

$$
\mathrm{DPR}=\frac{\mathrm{DPS}}{\mathrm{EPS}}
$$

4. Firm's Growth

Firm's Growth is calculated according to Farida et al., (2010) as:

$$
\mathrm{GRW}=\frac{\text { Total Assets }_{\mathrm{t}}-\text { Total Assets }_{\mathrm{t}-1}}{\text { Total Assets }_{\mathrm{t}-1}}
$$

5. Business Risk

Business Risk is calculated according to Horne and Wachowic (2005) as:

$$
\mathrm{RB}=\frac{\text { std deviasi earnings before interests and taxes }}{\text { average earnings before interests and taxes }}
$$

6. Liquidity

Liquidity is calculated according to Weygandt et al. (2013) as:

$$
\mathrm{CR}=\frac{\text { Current Assets }}{\text { Current Liabilites }}
$$

7. Profitability

Profitability is calculated according to Ross et al. (2012) as:

$$
\text { ROA }=\frac{\text { Net Income }}{\text { Total Assets }}
$$

\section{Analysis and Discussion}

This study meets the normality test and all the classical assumption test which consist of multicollinearity test, autocorrelation test, and heteroscedasticity test.

Table 1. Coefficient of determination test

Model Summary ${ }^{b}$ 


\begin{tabular}{|l|r|r|r|c|}
\hline Model & \multicolumn{1}{|c|}{$\mathrm{R}$} & R Square & Adjusted R Square & $\begin{array}{c}\text { Std. Error of the } \\
\text { Estimate }\end{array}$ \\
\hline 1 & $.793^{\mathrm{a}}$ & .628 & .582 & .118844616 \\
\hline
\end{tabular}

a. Predictors: (Constant), ROA, CR, KM, GWR, RB, KI, DPR

b. Dependent Variable: DTA

From Table 1, it can be seen that the coefficient correlation (R) is 0.793 . This suggests a strong positive correlation between the independent variable and debt policy as the value of $\mathrm{R}$ lies between +0.5 to +1.0 . The value of the adjusted $r$ square, shown in the amount of 0,582 , describes that the independent variable could define the dependent variable by $58,2 \%$.

Table 2. Significance Simultaneous Test (Test Statistic F)

\begin{tabular}{|rl|r|r|r|r|r|}
\hline \multicolumn{1}{|c|}{ Model $^{2}$} & Sum of Squares & df & Mean Square & F & Sig. \\
\hline \multirow{2}{*}{1} & Regression & 1.338 & 7 & .191 & 13.530 & $.000^{\mathrm{b}}$ \\
& Residual & .791 & 56 & .014 & & \\
& Total & 2.129 & 63 & & & \\
\hline
\end{tabular}

a. Dependent Variable: DTA

b. Predictors: (Constant), ROA, CR, KM, GRW, RB, KI, DPR

From Table 2, it can be seen that the F value of 13.530 has a significant level of 0.000 (below 0.05 ). This shows that the regression model can be used to predict the dependent variable, namely debt policy (DTA). Moreover, it can be concluded that all independent variables (ROA, CR, KM, GRW, RB, KI, and DPR) simultaneously, affect the DTA.

Table 3. Significant Test of Parameter Individual (Test Statistic t)

Coefficients $^{\mathrm{a}}$

\begin{tabular}{|c|c|c|c|c|c|c|}
\hline \multirow[t]{2}{*}{$\overline{\mathrm{Mod}}$} & & \multicolumn{2}{|c|}{ Unstandardized Coefficients } & \multirow{2}{*}{$\begin{array}{c}\begin{array}{c}\text { Standardized } \\
\text { Coefficients }\end{array} \\
\text { Beta }\end{array}$} & \multirow[t]{2}{*}{$\mathrm{t}$} & \multirow[t]{2}{*}{ Sig. } \\
\hline & & B & Std. Error & & & \\
\hline \multirow{8}{*}{1} & (Constant) & ,676 & ,091 & & 7,423 & ,000 \\
\hline & KM &,- 950 & ,330 &,- 325 & $-2,880$ & ,006 \\
\hline & KI &,- 167 & , 102 &,- 165 & $-1,645$ & , 105 \\
\hline & DPR &,- 044 & 079 &,- 061 &,- 563 & ,575 \\
\hline & GWR &,- 054 & 141 &,- 032 &,- 383 & ,703 \\
\hline & RB & 260 & , 100 & ,255 & 2,603 & ,012 \\
\hline & CR &,- 057 & ,007 &,- 742 & $-8,613$ & 000 \\
\hline & ROA & (093 & 203 & ,047 & , 461 & 646 \\
\hline
\end{tabular}

a. Dependent Variable: DTA

Based on the t-test result in Table 3, it can be seen that the total value of $\mathrm{t}$ for managerial ownership (KM) is $-2,880$, with a significant rate of 0,006 or lower than 0,05 . This could be concluded that Ha1 can be accepted, therefore, managerial ownership (KM) has a significantly negative correlation on debt policy.

From Table 3's t-test result, it is noted that the total value of $t$ for institutional ownership (KI) is $-1,645$, with a significant rate of 0,105 or higher than 0,05 . Thus, it can be concluded that $\mathrm{Ha} 2$ cannot be accepted, therefore, institutional ownership (KI) has no positive correlation on debt policy. The institutions had wished that firms would use debts to obtain the funds needed and to utilize these funds for the operation and to increase 
operational income. When the firms' operational income increases, the dividends distributed to stockholders, including the institutions, would be higher. However, if the firms utilized the fund for investments, and even if the cash flow of the firms taken from its operation were decreased, it would not be good for the firm.

Based on the t-test result, it can be seen that the total value of $t$ for dividend policy (DPR) is -1,645, with a significant rate of 0,575 or higher than 0,05 . This could be implied as saying that Ha3 cannot be accepted, therefore, dividend policy (DPR) has no negative correlation on debt policy. The average of dividends from observation had reached $43,4 \%$, which is high enough while the average debt had reached Rp9.369.216.146.011 indicating that the average debt had reached Rp10.612.482.570.142. These data imply that although the rate of dividend is fairly high, the debts used by the firms also remained high. This happened because the firms used the same fund for investment activities.

Based on the t-test result, the total value of $t$ for firm's growth (GRW) is $-0,383$ ) with a significant rate of 0,703 or higher than 0,05 . This could be interpreted as saying that $\mathrm{Ha}_{4}$ cannot be accepted. Thus, firm's growth (GRW) has no positive correlation on debt policy. The average of the asset's growth had reached 18,74\%, which is a decent value. The debt policy was measured with the assumption that firm assets were utilized for operation. In fact, the asset the firms obtained here were not entirely for operation, a big portion were for investments.

Based on the t-test results, it can be seen that the total value of $t$ for business risks (RB) is 2,603, with a significant rate of 0,012 or lower than 0,05 . This could be interpreted as saying that Has cannot be accepted, therefore, business risks (RB) has a positive correlation on debt policy. The average of business risks within observation is actually not that high, which is $18,66 \%$. From the data, it could be generalized that the manufacturing company in Indonesia has a low business risk and with this, creditors would be interested in lending funds.

Based on the $t$-test result, it can be seen that the total value of $t$ for liquidity (CR) is $-8,613$, with a significant rate of 0,000 or lower than 0,05 . This could be interpreted as saying that $\mathrm{Ha}_{6}$ cannot be accepted, therefore, liquidity (CR) has a negative correlation on debt policy. This happened because the firm's cash percentage within the current asset was surprisingly small, approximately $10 \%$. On the other hand, if the amount of the current debt was compared to current asset, the result would be nearly $30 \%$. In reality, the firms were only able to pay off part of their current debt. Nonetheless, creditors tend to observe the cash available within the firm.

Based on the t-test result, it can be seen that the total value of $t$ for profitability (ROA) is 0,461 , with a significant rate of 0,646 or higher than 0,05 . This could be interpreted as saying that $\mathrm{Ha}_{7}$ cannot be accepted, therefore, liquidity (CR) has no negative correlation on debt policy. The average of profitability, which is proxied by return on assets of the firm was quite low with the value of $13,29 \%$. When the firm acquired an asset that was not used for operation, it could be said to be an idle asset. Thus, this asset would not generate income for the firm. This explains why the ratio had no impact on debt policy.

Based on the table obtained, the regression equation used in this study, is as follows:

DTA $=-0.325 \mathrm{KM}-0.165 \mathrm{KI}-0.061 \mathrm{DPR}-0.032 \mathrm{GRW}+0.255 \mathrm{RB}-0.742 \mathrm{CR}+0.047 \mathrm{ROA}$

\section{Conclusion}

The conclusion that can be derived from this study includes: (1) Managerial ownership (KM) and liquidity (CR) have a significantly negative correlation on debt policy. Business risk (RB) has a significantly positive correlation on debt policy. Institutional ownership (KI) and firm's growth (GRW) have no significantly negative correlation on policy. Dividend policy (DPR) and profitability (ROA) have no significantly positive correlation on debt policy. (2) All of the independent variables were related to debt policy silmutaneously. This indicates that the regression model is an appropriate/fit in estimating the accrual value of the model. 


\section{References}

Hardiningsih, P., \& Oktaviani, R. M. (2012). Determinan Kebijakan Hutang Perusahaan. Dinamika Akuntansi, Keuangan, dan Perbankan 1(1), 11-24.

Farida, Y. N., Prasetyo, Y., \& Herwiyanti, E. (2010). Faktor-Faktor yang Mempengaruhi Struktur Modal. Jurnal Bisnis dan Akuntansi, 12(2), 81-96.

Kohardinata, C., \& Herdinata, C. (2013). Kepemilikan Manajerial dan Kepemilikan Institusional Terhadap Kebijakan Leverage Melalui Pendekatan Kesempatan Bertumbuh dan Risiko Perusahaan.

Murtiningtyas, A. (2012). Kebijakan Deviden, Kepemilikan Manajerial, Kepemilikan Institusional, Profitabilitas, Resiko Bisnis Terhadap Kebijakan Hutang. Accounting Analysis Journal Vol. 1(2), 1-6.

Nabela, Y. (2012). Pengaruh Kepemilikan Institusional, Kebijakan Dividen, dan Profitabilitas Terhadap Kebijakan Hutang Pada Perusahaan Properti dan Real Estate di Bursa Efek Indonesia. Jurnal Manajemen 1(1), 1-8.

Narita, R. (2012). Analisis Kebijakan Hutang. Accounting Analysis Journal Vol. 1(2), 1-6.

Nuraina, E. (2012). Pengaruh Kepemilikan Institusional dan Ukuran Perusahaan Terhadap Kebijakan Hutang dan Nilai Peruhsaaan. Jurnal Bisnis dan Ekonomi (JBE) 19(2), 110-125.

Ross, S., Westerfield, R., \& Jordan, B. (2012). Fundamental of Corporate Finance. McGraw Hill Higher Education.

Susanto, Y. (2011). Kepemilikan Saham, Kebijakan Dividen, Karakteristik Perusahaan, Risiko Sistematik, Set Peluang Investasi dan Kebijakan Hutang. Jurnal Bisnis dan Akuntansi 13(3), 195-210.

Weygandt J.J., Kimmel, P.D. \& Kieso D. E. (2013). Financial Accounting IFRS $2^{\text {nd }}$ Edition. John Wiley \& Sons.

Widjaja, I. 2014. Dampak Peningkatan Asset, Profitabilitas, dan Likuiditas Terhadap Leverage Perusahaan. Jurnal Akuntansi Vol. XVIII No. 03, 459-474.

www.bi.go.id

www.idx.co.id

Yeniatie, \& Destriana, N. (2010). Faktor-Faktor yang Mempengaruhi Kebijakan Hutang Pada Perusahaan Nonkeuangan yang Terdaftar di Bursa Efek Indonesia. Jurnal Bisnis dan Akuntansi Vol. 12 No. 1, 1-16. 